Article

\title{
Rapid Hydrolysis of Organophosphates Induced by U(IV) Nanoparticles: A Kinetic and Mechanistic Study using Spectroscopic Analysis
}

\author{
Hyejin Cho® and Wansik Cha *(1) \\ Nuclear Chemistry Research Division, Korea Atomic Energy Research Institute, Daedeok-daero, Yuseong-gu, \\ Daejeon 989-111, Korea; hcho921@kaeri.re.kr \\ * Correspondence: wscha@kaeri.re.kr
}

Received: 8 September 2019; Accepted: 20 November 2019; Published: 26 November 2019

\begin{abstract}
The heterogeneous interactions of colloidal U particles with organophosphates, leading to the formation of $U$-phosphate minerals, can retard the migration of $U$ in contaminated sites. Here, we studied the hydrolytic mechanism of $p$-nitrophenyl phosphate (NPP) on the surfaces of tetravalent uranium nanoparticles $\left(\mathrm{U}(\mathrm{IV})_{\mathrm{NPs}}\right)$, resulting in the formation of $\mathrm{U}$-phosphate precipitates. Our study shows that the reaction rate of NPP hydrolysis is significantly enhanced by $U(I V)_{N P s}$ through a multi-step heterogeneous reaction on the particle surfaces. The end products of the reaction were identified as $\mathrm{U}(\mathrm{IV})_{\mathrm{NPs}}$-aggregates with surface-bound phosphates. Colloidal properties, such as high positive values of the zeta-potential $(>+30 \mathrm{mV})$ and large surface areas of $\mathrm{U}(\mathrm{IV})_{\mathrm{NPs}}$ due to their unique cluster structures consisting of relatively small primary $\mathrm{UO}_{2}(\mathrm{cr})$-particles, are correlated with their reactivity towards hydrolysis reaction. Reaction kinetic modeling studies using spectrophotometric data indicated the presence of two distinct reaction intermediates as the surface complexes of NPP on $\mathrm{U}(\mathrm{IV})_{\mathrm{NPs}}$. We suggest the involvement of the NPP inner-sphere complexes in the rate-determining step based on the results obtained by analyzing the ATR-FTIR spectra and the surface-enhanced infrared absorption of NPP bound to substrate surfaces.
\end{abstract}

Keywords: tetravalent uranium nanoparticles $\left(\mathrm{U}(\mathrm{IV})_{\mathrm{NPs}}\right)$; organophosphates; $p$-nitrophenyl phosphate (NPP); hydrolysis; surface complexation; surface-enhanced infrared absorption; heterogeneous reaction mechanism

\section{Introduction}

Tetravalent uranium(U(IV)) is generally considered an immobile species under reducing repository conditions due to its low solubility and strong tendency to be retained at mineral surfaces [1]. It is recognized, however, that $\mathrm{U}(\mathrm{IV})$ in aqueous solution is dominated by colloidal species under reducing conditions [2]. The generation of such colloids/nanoparticles can increase the amount of $\mathrm{U}$ in groundwater, and is higher than expected from their thermodynamic solubility; consequently, enhancing the possibility of their migration [3]. Further, U's colloidal behaviors can be influenced by various interactions, such as adsorption, complexation, and surface reaction on colloidal particles, with mineral compounds and organic materials in environments $[4,5]$. Thus, a precise understanding of the colloid-facilitated transport of $U$ is required to establish the immobilization strategy of such colloids in U-contaminated sites.

Phosphates have been shown to immobilize $U$ by sorption [6,7] and by facilitating the precipitation of U-bearing phosphate minerals [8,9]. These strategies utilize the poor mobility of phosphate within sediments by adsorption onto mineral phases, co-precipitation with metals and radionuclides, and ion-exchange reactions [10]. Murray et al. observed that $U$ can be strongly adsorbed on apatite, 
which has a high capacity for retaining $U$ by phosphate mineralization [7]. Biotic approaches for immobilizing subsurface $U$ were also examined using microbial phosphatase activities that promote the in situ sequestration of $U$ as an insoluble phosphate mineral [11,12]. In the presence of organophosphates under reducing conditions, the biomineralization of $\mathrm{U}(\mathrm{VI})$-phosphate minerals has been shown to be more effective for removing $U$ than bioreduction to U(IV) species; e.g., uraninite. This is because biogenic $\mathrm{U}(\mathrm{IV})$ is considered to be prone to oxidative remobilization after exposure to oxygen or nitrate [13]. Furthermore, the ningyoite-like U(IV)-phosphate precipitates obtained by stimulating microbial U(VI) reduction in supplement with organophosphate (e.g., glycerol phosphate) exhibit high resistance to oxidative remobilization [12]. Also, mononuclear U(IV)-phosphate complexes and nanocrystalline $\mathrm{U}(\mathrm{IV})$ minerals were identified as major forms of $U$ in laboratory bioreduction settings as well as in lake sediments possessing rich organic matter [14,15]. However, the chemical mechanism of U-phosphate mineralization as well as the reactivities of each U(IV/VI) species involved has not been separately evaluated so far.

In fact, the occurrence of phosphate via the decomposition of organophosphates and its adsorption to mineral phases have been extensively studied to understand the fate and cycle of the phosphorous present in natural waters, sediments, and soils [16-21]. It has been shown that various insoluble minerals in aqueous media, including anatase $\left(\mathrm{TiO}_{2}\right)$, goethite $(\alpha-\mathrm{FeOOH})$, and $\mathrm{MnO}_{2}$, cause an increase in the rate of the hydrolysis of organophosphates [22-25]. Conversely, among the homogeneous catalytic systems in previous studies [26-31], highly charged metal cations, including lanthanides (Ln)(III), Ce(IV), and Th(IV), were found to be the most active complexes for the hydrolysis of phosphoesters [32-35]. These studies indicated that the Lewis acidities of these metals and the presence of bound hydroxide are crucial for stabilizing the transition state of phosphoester hydrolysis. However, due to the exceptionally low solubility of transition metal ions in aquatic environments, heterogeneous reactions involving suspended mineral phases, instead of homogeneous ones, may be crucial in the cycling of phosphorous.

To date, only few results regarding the interaction of $\mathrm{U}(\mathrm{IV})$ species with phosphate and organophosphates, which may accelerate or retard the migration of $U$, have been reported. In this study, we investigated the intrinsic reactivities of U(IV) toward the hydrolysis of phosphoesters using synthetic $\mathrm{U}(\mathrm{IV})$ species; i.e., a model U(IV) nanocolloidal system consisting of crystalline $\mathrm{UO}_{2}$ phases at various reaction conditions. Spectrophotometry-based hydrolysis kinetic analysis and reaction modeling analysis were employed to understand the detailed reaction mechanism of the surface-promoted hydrolysis of phosphoesters on the U(IV) nanoparticles. In particular, we exploited the surface-enhanced infrared absorption phenomena of a model phosphoester on U(IV) nanoparticles for the first time to examine the heterogeneous reaction mechanism and the molecular structures of the surface complexes.

\section{Materials and Methods}

All chemicals, including $p$-nitrophenyl phosphate disodium salt hexahydrate (NPP) and $p$-nitrophenol (NPH) (reagent grade, Sigma-Aldrich), were used as purchased. All procedures for the sample preparation were conducted in an Ar-filled glove box.

\subsection{Synthesis and Identification of U(IV) Species}

\subsubsection{U(IV) Nanoparticles (U(IV) $)_{\mathrm{NPs}}$ )}

The nanoparticle formation of U(IV) was induced in mild acidic aqueous solutions (pH 2-3). An aliquot of $\mathrm{U}(\mathrm{IV})$ stock solution (about $70 \mathrm{mM}$ ), which was electrochemically prepared in advance as described elsewhere [36], was added to a $0.1 \mathrm{M} \mathrm{NaClO}_{4}$ solution in a $25 \mathrm{~mL}$ vial to prepare a $3 \mathrm{mM}$ $\mathrm{U}(\mathrm{IV})$ solution. After $5 \mathrm{~h}$ of hydrothermal reaction at $90^{\circ} \mathrm{C}$, the solution's color changed from clear light blue to dark yellow. The U(IV) $)_{\mathrm{NPs}}$ we synthesized were stored in an Ar-filled glove box for subsequent use. High-resolution transmission electron microscopy (HR-TEM, JEOL, JEM 2001F) was applied to 
determine particle size, morphology, and crystalline structure. Furthermore, dynamic light scattering (DLS)-based particle size and zeta-potential of the nanoparticles were measured intermittently for up to 8 weeks to confirm their colloidal stability.

\subsubsection{Amorphous $\mathrm{U}(\mathrm{IV})-\mathrm{Hydroxides}(\mathrm{U}(\mathrm{IV})-\mathrm{OH}(\mathrm{am})$ )}

Due to the low solubility of U(IV), hydrolyzed forms of U(IV) can be rapidly prepared by adding an aliquot of the acidic U(IV) stock solution directly into neutral or basic aqueous solutions. Typically, amorphous solid $\mathrm{U}(\mathrm{IV})-\mathrm{OH}$ is obtained as bluish cloudy precipitates; i.e., a macro-scale solid phase network, that is normally accumulated at the bottom of a vessel as a soft cloudy layer, at room temperature.

\subsection{Particle Size and Zeta-Potential Measurements}

For characterization of the colloidal properties of the $\mathrm{U}(\mathrm{IV})_{\mathrm{NPs}}$, size and zeta-potential measurements were performed by the DLS method. Typically, $1 \mathrm{mM}$ of $\mathrm{U}(\mathrm{IV})_{\mathrm{NPs}}$ was prepared and subjected to measurements using a commercial DLS instrument (Zetasizer NanoZS, Malvern Instruments, Worcestershire, UK). The measurements were made at $25{ }^{\circ} \mathrm{C}$ in aqueous solutions containing $0.1 \mathrm{M} \mathrm{NaClO}_{4}$, which is the typical electrolyte level of the NPP hydrolysis reaction media in this study. The solution's $\mathrm{pH}$, ranging from 2 to 9, was adjusted using $0.1 \mathrm{M} \mathrm{NaOH}$. Moreover, following the manufacturer's suggestion (Malvern Instruments), we applied the Smoluchowski approximation to calculate the zeta-potential (see SI for the measurement parameters). The data were collected and averaged from the zeta-potential average values of three runs. For the amorphous solid U(IV)-OH, its size distribution was too large to measure by DLS analysis.

\subsection{Spectrophotometric Reaction Kinetic Analysis}

The rates of the hydrolysis of NPP by U(IV) species were measured spectrophotometrically by monitoring the increase in the absorbance at $400 \mathrm{~nm}$, which is the $\lambda_{\max }$ of the reaction product, p-nitrophenolate (NP). A spectrophotometer (MCS601, Carl Zeiss, Jena, Germany) equipped with a temperature-controlled cell holder (Qpod 2e, Quantum Northwest, USA) was used for the measurements. Typically, aqueous solutions of $0.5 \mathrm{mM} \mathrm{NPP}$ and $3 \mathrm{mM} \mathrm{U}(\mathrm{IV})$ species were prepared in $0.1 \mathrm{M} \mathrm{NaClO}_{4}$ and used for the sample preparation. A total of $300 \mu \mathrm{L}$ of $0.5 \mathrm{mM} \mathrm{NPP}$ was added to $2.7 \mathrm{~mL}$ of $0.1 \mathrm{M} \mathrm{NaClO}_{4}$ solution in a quartz cuvette (cell path length of $1 \mathrm{~cm}$ ). The $\mathrm{pH}$ was controlled by the addition of $0.1 \mathrm{M} \mathrm{NaOH}$ prior to the addition of the NPP. The reaction was typically initiated by the injection of $100 \mu \mathrm{L}$ of a $3 \mathrm{mM} \mathrm{U}$ (IV) solution (pH: 2.3) into the mixed solution when the temperature-controlled cell holder was set at the desired temperature $\left(25\right.$ or $\left.50^{\circ} \mathrm{C}\right)$.

\subsection{ATR-FTIR Measurements}

Two sets of FTIR experiments for the NPP hydrolysis study were conducted using a spectrometer (Nicolet iS10 ${ }^{\mathrm{TM}}$, Thermo Scientific) equipped with a single ATR module (GladiATR ${ }^{\mathrm{TM}}$, Pike Technologies) for solid samples and a 9-reflection diamond ATR module (LR-D-M, Durasens LLC) containing a liquid flow cell for liquid samples. Aqueous solutions of $0.15 \mathrm{mM} \mathrm{NPP}$ or phosphate with $1.5 \mathrm{mM} \mathrm{U}(\mathrm{IV})_{\mathrm{NPs}}$ in $0.1 \mathrm{M} \mathrm{NaClO}_{4}$ were stirred overnight at room temperature and subsequently centrifuged for $2 \mathrm{~h}$ with 132,380 RCF. The supernatant was removed and the remaining precipitate was washed with $0.01 \mathrm{M} \mathrm{HCl}$ to eliminate $\mathrm{ClO}_{4}{ }^{-}$. The precipitate- $\mathrm{HCl}$ mixed solution was centrifuged for $0.5 \mathrm{~h}$ with $132,380 \mathrm{RCF}$. The supernatant was removed and the washed precipitates were freeze-dried for $3-4 \mathrm{~h}$ to obtain powder samples for the measurements. Alternatively, $U(I V)_{\mathrm{NPs}}$ for the other IR experiments were prepared in a chloride medium instead of perchlorate due to the presence of a strong perchlorate absorption band around $900-1100 \mathrm{~cm}^{-1}$ in the spectra. Aqueous solution mixtures of NPP and U(IV) $)_{\mathrm{NPs}}$ were prepared at various concentrations and $\mathrm{pH}$ levels, after which they were introduced within $10 \mathrm{~min}$ to the flow cell on the ATR-FTIR module for the measurements at room temperature. 


\subsection{Reaction Modeling Analysis}

A reaction modeling study was conducted to confirm the measured reaction rate and the proposed reaction mechanism using the ReactLab KINETICS software (JPlus Consulting, East Fremantle, WA, Australia). The UV-Vis spectrophotometric data obtained from the reaction kinetic monitoring experiments were analyzed by the program. The global fitting of the reaction data was performed using a two-step reaction sequence.

\section{Results and Discussion}

\subsection{Characterization of $U(I V)_{N P S}$}

A hydrothermally induced $\mathrm{U}(\mathrm{IV})_{\mathrm{NPs}}$ preparation method was developed using acidic $\mathrm{U}(\mathrm{IV})$ aqueous solutions ( $\mathrm{pH} \sim 2$ ). The acidity and concentration of $\mathrm{U}(\mathrm{IV})$, typically $3 \mathrm{mM}$ in $0.1 \mathrm{M} \mathrm{NaClO}_{4}$ solution, were controlled passively; i.e., by the dilution of an acidic $\mathrm{U}(\mathrm{IV})$ stock solution $(\mathrm{pH}<1)$. We confirmed that the dominant $\mathrm{U}(\mathrm{IV})$ species before and after the synthesis were $\mathrm{UOH}^{3+}(\mathrm{aq})$ and $\mathrm{U}(\mathrm{IV})_{\mathrm{NPs}}$, respectively (see Figure $\mathrm{S} 1$ ). The synthesis, storage, and tests of $\mathrm{U}(\mathrm{IV})_{\mathrm{NPs}}$ were carried out under anaerobic conditions; e.g., in an Ar-filled glove box.

Figure $1 \mathrm{a}$, b shows the transmission electron microscopy (TEM) images exhibiting a characteristic raspberry-type cluster morphology of $\mathrm{U}(\mathrm{IV})_{\mathrm{NPs}}$ and crystalline- $\mathrm{UO}_{2}$ internal structures of relatively small primary particles. The primary particles had a size distribution ranging from 3 to $6 \mathrm{~nm}$ based on the TEM image analysis. Interestingly, the presence of primary particles could not be detected by dynamic light scattering (DLS) analysis, the results of which display that $\mathrm{U}(\mathrm{IV})_{\mathrm{NPs}}$ clusters were a major form of nanoparticles in aqueous solutions. The resulting $\mathrm{U}(\mathrm{IV})_{\mathrm{NPs}}$ clusters were uniformly dispersed in the solution and exhibited rather monodisperse size distribution (see Figure S2), typically with the average cluster size of $23 \pm 6 \mathrm{~nm}$ (uncertainty obtained from the results of several batches of $\left.\mathrm{U}(\mathrm{IV})_{\mathrm{NPs}}\right)$. Thus, in this article we use the term, $\mathrm{U}(\mathrm{IV})_{\mathrm{NPs}}$, to indicate the clusters of $\mathrm{U}(\mathrm{IV})$ primary particles, unless otherwise noted. We confirm that $\mathrm{U}(\mathrm{IV})_{\mathrm{NPs}}$ are stable in an acidic solution (pH 1.5-2.4) over 8 weeks at room temperature, although in metastable colloidal states (see Figure 1c,d).
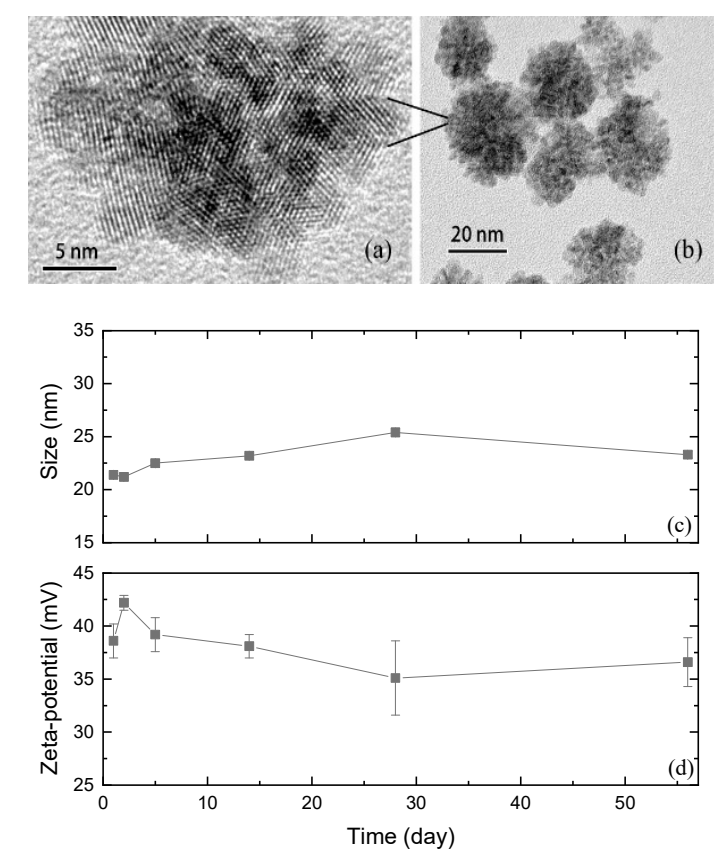

Figure 1. Characteristics of $\mathrm{U}(\mathrm{IV})_{\mathrm{NPs}}$ synthesized in this study; TEM images showing (a) crystalline internal structures of primary particles and (b) their clusters of nominal particle sizes $(20-30 \mathrm{~nm})$; (c) particle size and (d) zeta-potential measurements of $1 \mathrm{mM} \mathrm{U}(\mathrm{IV})_{\mathrm{NPs}}$ in $0.1 \mathrm{M} \mathrm{NaClO}_{4}$ at $\mathrm{pH} 2.3$ over time by DLS. 
The acidic stock solutions of the synthesized $\mathrm{U}(\mathrm{IV})_{\mathrm{NPs}}$ display highly positive zeta-potential values in the range of +35 to $+40 \mathrm{mV}$, providing a good explanation of the colloidal stabilities of these nanoparticles over the extended period (see Figure 1d). Thus, it is very likely that the inter-particle Coulombic repulsion resulting from the surface charges is a critical interfacial determinant of the colloidal stabilities of $\mathrm{U}(\mathrm{IV})_{\mathrm{NPs}}$ and their reproducible particle/cluster sizes. More importantly, such a positive surface charge is a strong indicator of the presence of partially hydrolyzed surface structures, such as $\equiv \mathrm{U}(\mathrm{OH})^{+}$on the crystalline primary particles; i.e., the intermediate structures between $\mathrm{UO}_{2}(\mathrm{cr})$ and $\mathrm{U}(\mathrm{OH})_{\mathrm{n}}{ }^{4-\mathrm{n}}(\mathrm{aq})$. The occurrence of such intermediate structure formation has been proposed in previous studies on iron oxide nanoparticle formation [37].

The size and zeta-potential values of the $\mathrm{U}(\mathrm{IV})_{\mathrm{NPs}}$ were measured for a wide range of $\mathrm{pHs}$ to identify their colloidal properties under various reaction conditions of the NPP hydrolysis. Without $\mathrm{pH}$ adjustment, the $\mathrm{pH}$ of the $1 \mathrm{mM}$ sample, which was prepared from a $\mathrm{U}(\mathrm{IV})_{\mathrm{NPs}}$ stock solution, was approximately 2.3, as shown in Figure 1c,d. By the addition of $0.1 \mathrm{M} \mathrm{NaOH}$, the size of U(IV) $)_{\mathrm{NPs}}$ clusters increases with the solution $\mathrm{pH}$, as shown in Figure S3. At a relatively high $\mathrm{pH}$, it appears that the U(IV) $)_{\mathrm{NPs}}$ clusters start aggregating by forming relatively large clusters up to the micrometer scale. In fact, the zeta-potential values decrease slightly but remain at positive up to $\mathrm{pH} 8$. However, the zeta-potential values of the $\mathrm{U}(\mathrm{IV})_{\mathrm{NPs}}$ became negative $(<-20 \mathrm{mV})$ at $\mathrm{pH} 9$. The isoelectric point was found to be located approximately at $\mathrm{pH} 8.6$, although precise $\mathrm{pH}$ control was difficult at that $\mathrm{pH}$ region. Thus, it was expected that the sizes of the $\mathrm{U}(\mathrm{IV})_{\mathrm{NPs}}$ were maintained at approximately in the range of 250-650 nm during the NPP hydrolysis that was examined in this study.

\subsection{Comparison of NPP Hydrolysis Rates by Different U(IV) Species}

The hydrolysis of NPP was investigated with two different types of U(IV) species, including $\mathrm{U}(\mathrm{IV})_{\mathrm{NPs}}$ and amorphous $\mathrm{U}(\mathrm{IV})$-hydroxides (U(IV)-OH(am)). The detailed preparation procedures for each species are provided in the Materials and Methods Section. The strong absorptivities of NPP and NP were exploited to monitor the reaction kinetics by UV-Vis spectroscopy, as shown in Figure 2 . The spectra were within the range of $210-500 \mathrm{~nm}$, where the characteristic $\lambda_{\max }$ values of NPP (plus NPPH and the reaction intermediates) and NP appeared at 290-310 $\mathrm{nm}$ ( $a$ and $b_{1}$ in Figure 2 ) and at $400 \mathrm{~nm}\left(\mathrm{~b}_{2}\right)$, respectively.

Interestingly, our reaction kinetic monitoring system shows that the NPP hydrolysis with $U(I V)_{N P s}$ occurred via a multi-step reaction pathway involving a very rapid NPP-U(IV) $)_{\mathrm{NPs}}$ complexation. As shown in Figure 2, a series of transient spectra (dashed lines) indicated by an arrow (a) appeared immediately after the injection of $\mathrm{U}(\mathrm{IV})_{\mathrm{NPs}}$ into the NPP solution at $\mathrm{pH}$ 7.5. These spectra are distinct from that of NPP (a dianionic form, $\mathrm{p} K_{a} 5.1$ ), and the initial spectrum of the series ("a" in Figure 2) exhibits a band shape similar to that of NPPH. Therefore, we attribute the initial spectrum to the first intermediate (I1). The formation of I1 was immediate and far faster than the following steps, and thus could not be measured in our typical data collecting interval $(2 \mathrm{~s})$. Thus, the band shift shown in series (a) during the initial $30 \mathrm{~s}$ (dashed lines in Figure 2) was interpreted as a subsequent transformation of I1 to another more stable intermediate (I2). The absorption spectra of the reaction mixture collected at $25^{\circ} \mathrm{C}$ (see Figure S4a) also demonstrates that the band shift pattern is similar to that recorded at $50{ }^{\circ} \mathrm{C}$ (see Figure 2) except regarding the reaction rate. The initial process (a) (dashed lines) takes about $200 \mathrm{~s}$ at $25^{\circ} \mathrm{C}$ reaction and $30 \mathrm{~s}$ at $50{ }^{\circ} \mathrm{C}$ reaction. Thus, it is concluded that both reactions at 25 and $50{ }^{\circ} \mathrm{C}$ follow the same reaction pathway accompanying the initial changes (a) in Figure 2 . However, such transient spectra were not observed in the spectra obtained from the NPP hydrolysis with U(IV)-OH(am) (see Figure S4b). More details about I1 and I2 are included in Section 3.3 below, which describes the mechanistic studies on the hydrolysis of NPP.

The absorption spectra of NPP and NP at various concentrations and $\mathrm{pH}$ ranges are represented in Figure S5 and were applied to convert the absorbance values to the concentration of each species. Pseudo-first order rate constants $\left(k_{o b s}\right)$ were calculated from the absorbance increase at $400 \mathrm{~nm}\left(\lambda_{\max }\right.$ of NP, $\epsilon=18,500 \mathrm{~cm}^{-1} \mathrm{M}^{-1}$ ) over a period sufficient for a $10 \%$ reaction conversion to be achieved 
(normally up to $100 \mathrm{~s}$, indicated as a dotted line in the inset plot of Figure 2). The rate constants obtained as the mean values from triplicate runs with $\pm 10 \%$ reproducibility are summarized in Table 1 (The equations for calculating the rate constants are provided in Supplementary Materials).

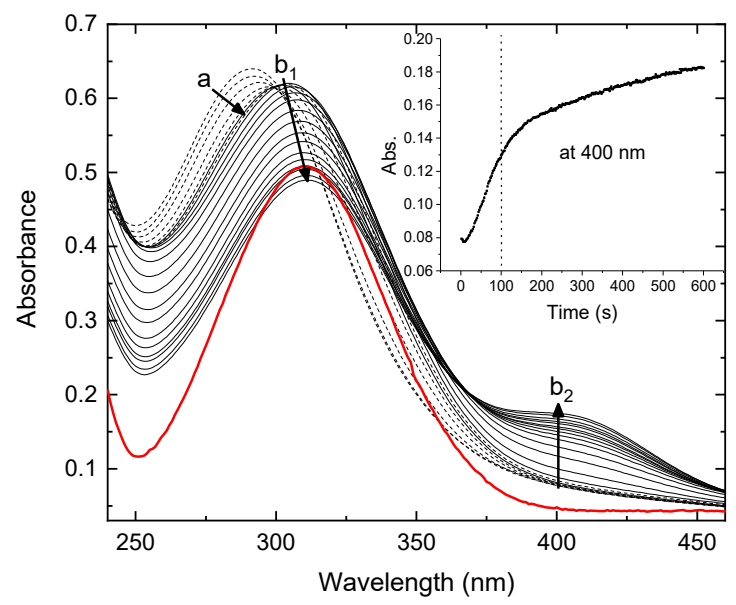

Figure 2. Absorption spectra of the free NPP (thick red) and reaction mixture (black) collected for initial $600 \mathrm{~s}\left([\mathrm{NPP}]=50 \mu \mathrm{M},\left[\mathrm{U}(\mathrm{IV})_{\mathrm{NPs}}\right]=100 \mu \mathrm{M}\right.$ in $0.1 \mathrm{M} \mathrm{NaClO}_{4}, \mathrm{pH}=7.5,50^{\circ} \mathrm{C}$ ); dashed lines (arrow a): initial transition between two intermediates adsorbed on the surfaces of $\mathrm{U}(\mathrm{IV})_{\mathrm{NPs}}$; solid black lines: reduction of intermediate 2 (arrow $b_{1}$ ); and formation of reaction product NP: arrow $b_{2}$.

To identify the active species actually responsible for the rapid hydrolysis by $\mathrm{U}(\mathrm{IV})_{\mathrm{NPs}}$, the reactivities of the $\mathrm{U}(\mathrm{IV})-\mathrm{OH}(\mathrm{am})$ were compared. For $\mathrm{U}(\mathrm{IV})-\mathrm{OH}(\mathrm{am})$, the formation of $\mathrm{UO}_{2} \cdot \mathrm{xH}_{2} \mathrm{O}(\mathrm{am})$ was prevalent over a wide $\mathrm{pH}$ range. At low $\mathrm{pH}(<5)$, hydrolyzed $\mathrm{U}(\mathrm{IV})$ species such as oligomeric $\mathrm{U}(\mathrm{IV})-\mathrm{OH}$ species mayexist. Hypothetically, $\mathrm{U}(\mathrm{IV})_{\mathrm{NPs}}$ may not be the reactive species and may slowly transform into a more thermodynamically stable and more reactive U(IV) species for phosphoester hydrolysis after addition into a given test solution. However, $\mathrm{U}(\mathrm{IV})-\mathrm{OH}(\mathrm{am})$ and other $\mathrm{U}(\mathrm{IV})$ species were found to be less reactive than the $\mathrm{U}(\mathrm{IV})_{\mathrm{NPs}}$, as shown in Table 1 . Thus, we concluded that the high reaction rates of $\mathrm{U}(\mathrm{IV})_{\mathrm{NPs}}$ originated from their intrinsic physicochemical properties, such as particle size, surface charge, and chemical structure.

Table 1. Comparison of the kinetic data of $\mathrm{U}(\mathrm{IV})$ and other metal ions for inducing NPP hydrolysis.

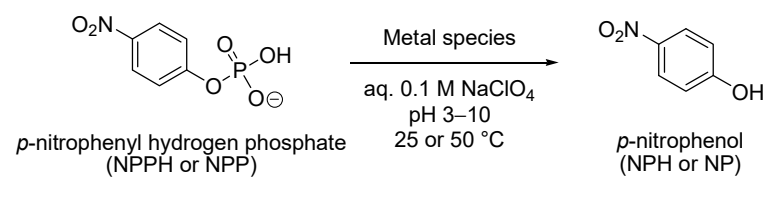

\begin{tabular}{|c|c|c|c|c|c|c|c|}
\hline \multirow{2}{*}{ Metal Species } & \multirow{2}{*}{$\begin{array}{c}\mathrm{T} \\
\left({ }^{\circ} \mathrm{C}\right)\end{array}$} & \multicolumn{5}{|c|}{$k_{\mathrm{obs}} / 10^{-4} \mathrm{~s}^{-1}$} & \\
\hline & & pH $3.3 \pm 0.2$ & pH $5.2 \pm 0.2$ & pH $6.1 \pm 0.2$ & pH $7.2 \pm 0.3$ & pH $9.3 \pm 0.2$ & \\
\hline $\mathrm{U}(\mathrm{IV})_{\mathrm{NPs}}$ & 25 & 0.90 & 1.1 & 1.2 & 1.4 & 0.21 & \multirow{4}{*}{$\begin{array}{l}\text { this work } \\
\text { [a] }\end{array}$} \\
\hline & 50 & 15 & 16 & 19 & 20 & 2.2 & \\
\hline \multirow[t]{2}{*}{$\mathrm{U}(\mathrm{IV})-\mathrm{OH}(\mathrm{am})$} & 25 & 0.24 & 0.23 & 0.21 & 0.17 & 0.080 & \\
\hline & 50 & 2.4 & 2.3 & 2.2 & 1.7 & 0.82 & \\
\hline $\begin{array}{l}\mathrm{U}(\mathrm{VI}), \mathrm{Th}(\mathrm{IV}) \\
\mathrm{La}(\mathrm{III})\end{array}$ & 37 & & $0.095\left(\mathrm{UO}_{2}{ }^{2+}\right)^{[\mathrm{b}]}$ & $280\left(\mathrm{Th}^{4+}\right)^{[\mathrm{c}]}$ & $0.0014\left(\mathrm{La}^{3+}\right)^{[\mathrm{d}]}$ & & $\begin{array}{c}\text { ref. } \\
\text { [37-39] }^{[\mathrm{f}]}\end{array}$ \\
\hline $\mathrm{Ce}(\mathrm{IV})^{[\mathrm{e}]}$ & 50 & & & 180 & 260 & 190 & $\begin{array}{c}\text { ref. } \\
{[40,41]^{[f]}}\end{array}$ \\
\hline
\end{tabular}

[a] $\mathrm{pH}$ : the average values of each reaction; conditions: [substrate] $=50 \mu \mathrm{M},[\mathrm{U}(\mathrm{IV})]=100 \mu \mathrm{M}$ in $0.1 \mathrm{M} \mathrm{NaClO}_{4}$. Kinetic data were collected at $400 \mathrm{~nm}$; for [b], [c], [d], and [e], 10-fold, 20-fold, 2.5-fold (at $25^{\circ} \mathrm{C}$ ), and 40 -fold excesses of metal over substrate were used, respectively; [f] bis(4-nitrophenyl) phosphate was used as the substrate of the hydrolysis. 
The level of the hydrolysis rate enhancement of $\mathrm{U}(\mathrm{IV})_{\mathrm{NPs}}$ is comparable (i.e., about an order lower) to that of $\mathrm{Ce}(\mathrm{IV})$ and is also ca. 200 and $10^{3}$ times higher than those of the $\mathrm{UO}_{2}{ }^{2+}$ and $\mathrm{La}^{3+}$ catalyzed cleavages, respectively (see Table 1). We employed a 2-fold excess of U(IV) over the substrates, which is a much smaller amount compared to those reported previously (2.5-40-fold excess) [38-42] because the high concentration of metal can induce significant precipitation of metal at a high $\mathrm{pH}$ range. To compare the reactivities of other metals, the U(IV) concentration in a solution is expressed in molar units. Thus, it represents the total $U$ content added into the reaction solution, not that of active or/and dissolved U species only.

The reactions with $\mathrm{U}(\mathrm{IV})_{\mathrm{NPs}}$ exhibited a characteristic $\mathrm{pH}$ dependency, i.e., a gradual increase up to $\mathrm{pH} 7$, followed by a drastic decrease at a $\mathrm{pH}$ higher than 7 (see Table 1). Such a reduction in the reactivity indicates that the bulk hydroxide ions in an aqueous phase do not act as a nucleophile to attack the phosphorus center. Instead, the NPP hydrolysis at $\mathrm{pH} 7$ and lower is facilitated by the surface-bound hydroxides on the nanoparticles. The sharp decrease in the rate at $\mathrm{pH}>7$ can be explained well by the colloidal destabilization, including particle aggregation and the surface potential changes from positive to negative values (see Figure S3). Thus, the adsorption of the NPP can be dependent on $\mathrm{pH}$ and affect the reaction rate; at higher $\mathrm{pH}$ the surface of $\mathrm{U}(\mathrm{IV})_{\mathrm{NPs}}$ is no more effective to attract ligands and catalyze NPP hydrolysis. Conversely, the low-pH reaction rate is slightly higher than those obtained from high $\mathrm{pH}$ solutions for $\mathrm{U}(\mathrm{IV})-\mathrm{OH}(\mathrm{am})$. Even for this modest increase in reactivity, we speculate that the U(IV) $)_{\mathrm{NPs}}$ formed from hydrolyzed U(IV) species probably play a role, because $\mathrm{U}(\mathrm{IV})_{\mathrm{NPs}}$ clusters or primary particles can be gradually produced over time under mild acidic conditions.

Further spectrophotometric analysis was conducted by varying the NPP and U(IV) $)_{\mathrm{NPs}}$ concentrations. As shown in Figure S6, the initial rate depends on the NPP concentration. By increasing the NPP concentration from $25 \mu \mathrm{M}$ to $100 \mu \mathrm{M}$, the rate constant $\left(k_{o b s}\right)$ increases from $7.5 \times 10^{-3} \mathrm{~s}^{-1}$ up to $3.1 \times 10^{-2} \mathrm{~s}^{-1}$, which is ca. $10^{6}$ times greater than that of the reaction without any metal complexes $\left(k_{o b s}=3.3 \times 10^{-8} \mathrm{~s}^{-1}\right)$ [43]. At a fixed substrate concentration $(50 \mu \mathrm{M} \mathrm{NPP})$, the reaction rate was also found to be proportional to the $\mathrm{U}(\mathrm{IV})_{\mathrm{NPs}}$ concentration; the rate constant of $1.1 \times 10^{-2} \mathrm{~s}^{-1}$ in Figure S6 with $500 \mu \mathrm{M} \mathrm{U}(\mathrm{IV})_{\mathrm{NPs}}$ is almost five times greater than that from Table 1 for $100 \mu \mathrm{M} \mathrm{U}(\mathrm{IV})_{\mathrm{NPs}}$. In addition, it should be noted that after the rapid initial stage, the reaction slows down, as shown in the inset of Figure 2 (>100 s). Such a decrease in the reaction rate is largely due to the reduction in the substrate concentration. However, we suppose that the surface poisoning effect is also involved in $\mathrm{U}(\mathrm{IV})_{\mathrm{NPs}}$ via the phosphate ion that remained bound after the release of NP.

\subsection{Mechanistic Studies on the NPP Hydrolysis}

\subsubsection{ATR-FTIR Studies and SEIRA}

Here, surface-enhanced infrared absorption (SEIRA) was employed for the first time to study the reaction mechanism of NPP hydrolysis on the surfaces of $U(I V)_{N P s}$. SEIRA is a near-field phenomenon, in which the IR absorption of molecules adsorbed on or in the vicinity of small metal/metal oxide-clusters is enhanced by a factor of 10 to 1000 due to the electrical field around the clusters [44]. The surface selection rule of SEIRA implies that only the vibrational modes inducing dynamic dipole moments perpendicular to the surface will be enhanced, which can provide the structural information regarding the bound molecules and their orientation [45]. Usually, p-nitrobenzoic acid or its derivatives are used as model substrates. In this study, we report that U(IV) $)_{\text {NPs }}$ induce SEIRA for NPP. As demonstrated in Figure 3a, the overall IR absorption of $5 \mathrm{mM}$ NPP is enhanced in the presence of $1 \mathrm{mM} \mathrm{U}(\mathrm{IV})_{\mathrm{NPs}}$. The strong band at $1350 \mathrm{~cm}^{-1}$ has been assigned as a symmetric $\mathrm{NO}_{2}$ stretching vibrational mode in previous SEIRA studies and is used to examine the molecular orientation of the ligand adsorbed on noble metal-based and metal oxide-based nanoparticle systems [46,47]. For the enhanced IR spectrum in Figure 3a, both surface bound and unbound NPP molecules contribute to the IR absorption, while free (unbound) NPP remains dominant. 
Figure $3 b$ shows the SEIRA effect more clearly. Without $U(I V)_{N P s}$ the band at $1350 \mathrm{~cm}^{-1}$ is overly weak in a solution of $0.1 \mathrm{mM} \mathrm{NPP}$, and cannot be detected in a given ATR-FTIR setting (dashed line, and see Figure S7a for the full spectrum); however, the addition of $0.1 \mathrm{mM} \mathrm{U}(\mathrm{IV})_{\mathrm{NPs}}$ significantly enhances the intensities of the peaks. The enhancement factor is ca. 100 in the presence of $1 \mathrm{mM}$ of $\mathrm{U}(\mathrm{IV})_{\mathrm{NPs}}$; however, no further increase is obtained by adding more than $1.5 \mathrm{mM} \mathrm{U}(\mathrm{IV})_{\mathrm{NPs}}$, probably due to the full adsorption of phosphoesters onto the nanoparticle surfaces [48]. To further evaluate the SEIRA of NPP, the NPP concentration was varied at a fixed concentration of U(IV) $)_{\mathrm{NPs}}(1 \mathrm{mM}$, see Figure S8). The SEIRA was only observed up to a certain level of NPP concentration (ca. $1 \mathrm{mM}$ ), where the surface saturation of $U(I V)_{N P s}$ with NPP was attained. Overall, such SEIRA effects indicate that the crystalline primary particles of $\mathrm{U}(\mathrm{IV})_{\mathrm{NPs}}$ possessing $\mathrm{UO}_{2}$-like semiconductor properties can effectively create polarized local electromagnetic fields interacting with the oscillating dipoles of the adsorbed molecules $[46,47]$.
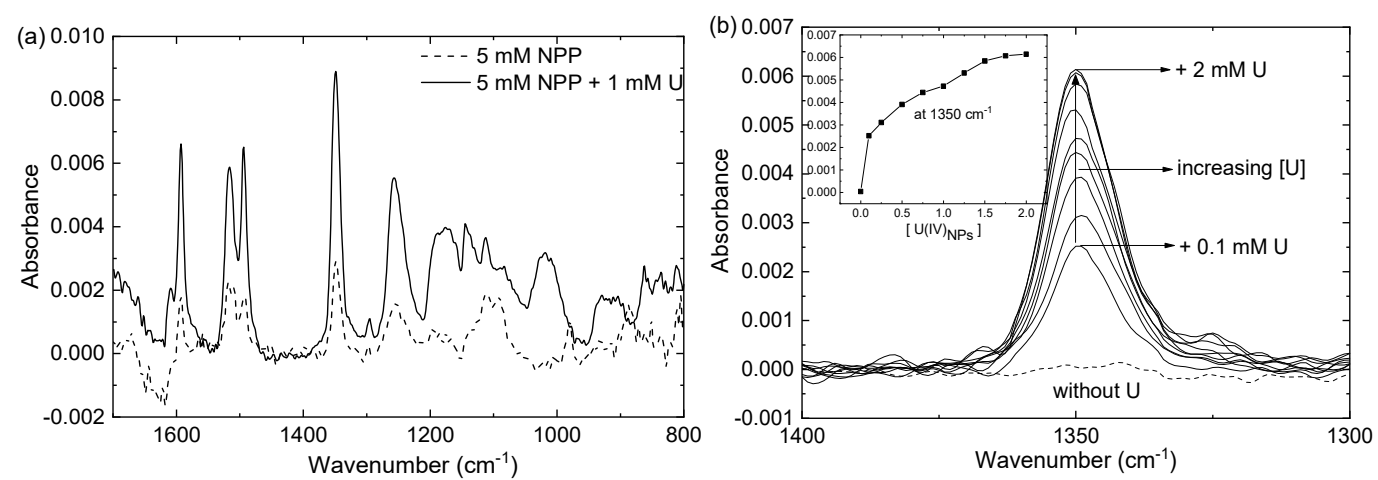

Figure 3. ATR-FTIR spectra of the reaction mixture exhibiting SEIRA effects at pH 5.2. (a) New peaks are observed in the spectrum of NPP in the presence of $U(I V)_{\text {NPs }}$ (solid) compared to the case with the free NPP (dashed). (b) Expanded spectra at 1300-1400 $\mathrm{cm}^{-1}$ (dashed line: $0.1 \mathrm{mM}$ NPP without $\mathrm{U}(\mathrm{IV})_{\mathrm{NPs}}$; solid lines: upon addition of $0.1-2 \mathrm{mM} \mathrm{U}(\mathrm{IV})_{\mathrm{NPs}}$ to $0.1 \mathrm{mM} \mathrm{NPP}(\mathrm{pH} 3.2-2.0)$ ).

The SEIRA spectrum of NPP bound to U(IV) $)_{\mathrm{NPs}}$ (Figure $\mathrm{S7b}$ ) was further examined to elucidate its spectral difference from that of the free NPP in the low frequency region, where the vibrational modes of the phosphate groups were dominant. The SEIRA spectrum of NPP-U(IV) NPs $_{\text {( }}$ (red line in Figure S7b) exhibits two discrete vibrational bands compared with that of the free NPP (black line in Figure $\mathrm{S} 7 \mathrm{~b}$ ) at $\sim 1150$ and $\sim 1025 \mathrm{~cm}^{-1}$. In this spectrum, the characteristic $\mathrm{P}-\mathrm{O}$ and $\mathrm{P}-\mathrm{OH}$ bands of the free phosphates occurring at approximately 1200,1080 , and $980 \mathrm{~cm}^{-1}$ are absent. In previous studies for a phosphomonoester-ferrihydrite or -goethite system, the authors assigned the bands near $1150 \mathrm{~cm}^{-1}$ and $1030 \mathrm{~cm}^{-1}$ to the $\mathrm{P}-\mathrm{O}$ vibrations, which indicated the significant distortions of the $\mathrm{P}-\mathrm{O}$ bonds as phosphomonoesters coordinated to goethite $[25,49,50]$. Additionally, in their structural interpretation of phosphate/phosphonate surface complexes, either a bidentate coordination or a monodentate coordination in combination with hydrogen bonding to neighboring surface oxometallic sites was favored [25,49-51]. Thus, in the NPP-U(IV) NPs system, we speculate that inner-sphere surface complexes are formed on $\mathrm{U}(\mathrm{IV})_{\mathrm{NPs}}$, and more specifically, two terminal oxygens of the phosphate are fully coordinated to the particle surfaces; i.e., in a bidentate fashion. This arrangement may contribute to the SEIRA effect of the NPP-U(IV) $)_{\mathrm{NPs}}$ system by preferentially enhancing vibrational modes that have dipole moment derivative components perpendicular to the surface [48]. In this study, this surface complex was considered to be one of the reaction intermediates, particularly one that was accumulated at the rate-determining step.

\subsubsection{ATR-FTIR Spectra of Solid Phase U(IV) $)_{\mathrm{NPs}}$}

ATR-FTIR spectroscopic analyses were performed to further investigate the surface adsorption of phosphoester/phosphate on the surfaces of $\mathrm{U}(\mathrm{IV})_{\mathrm{NPs}}$. To identify the surface complex of the final 
reaction product, two parallel samples, one with NPP and the other with phosphate, were prepared at $\mathrm{pH}$ 7. Under our experimental conditions, an excess amount (10 equiv) of $\mathrm{U}(\mathrm{IV})_{\mathrm{NPs}}$ was used to complete the reaction ( $100 \%$ conversion of NPP to NP) and the precipitate was formed after the hydrolysis of NPP. Figure 4 shows the spectra of the dried precipitates from each reaction. The positions of peaks $\left(1100,1030,920\right.$, and $860 \mathrm{~cm}^{-1}$ ) from the NPP reaction precipitate (solid line in Figure 4) are almost identical to the phosphate reaction precipitate (dashed line in Figure 4), which shifted from the peaks of the phosphate solution $(\mathrm{pH} 7)$ without $\mathrm{U}(\mathrm{IV})_{\mathrm{NPs}}$. In previous studies, Arai and Sparks also observed similar peak positions in the spectra of phosphate adsorbed on goethite surfaces [51]. We, therefore, conclude that the model phosphoester, NPP, was finally decomposed to the phosphate surface complex on the $\mathrm{U}(\mathrm{IV})$ precipitates at $\mathrm{pH} 7$ by the hydrolysis.

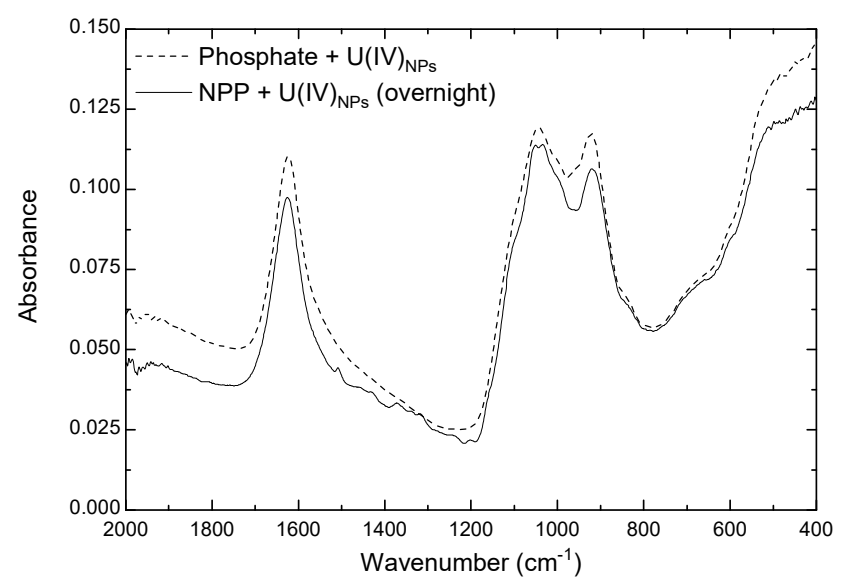

Figure 4. ATR-FTIR spectra of the dried precipitates from each of the two reactions: one with phosphate and the other with NPP. [U(IV) $\left.)_{\mathrm{NPs}}\right]=1.5 \mathrm{mM}$, [Substrate] $=0.15 \mathrm{mM}, I=0.1 \mathrm{M} \mathrm{NaClO}_{4}$ at $\mathrm{pH} 7,25^{\circ} \mathrm{C}$, overnight.

Based on our findings, a multi-step reaction mechanism for the hydrolysis of NPP was postulated, as illustrated in Scheme 1. In this mechanism, the reaction starts with the immediate adsorption of NPP on the surface of the U(IV) $)_{\mathrm{NPs}}$ to form a surface complex, I1, as an outer-sphere U(IV) $)_{\mathrm{NPs}}-\mathrm{NPP}$ complex. Subsequently, I1 rapidly changes its structure to the more stable complex (I2) that exhibits SEIRA. An intramolecular attack on $I 2$ by the surface-bound hydroxide available on $\mathrm{U}(\mathrm{IV})_{\mathrm{NPs}}$ is the rate-determining step (r.d.s.) for the release of the products, $p$-nitrophenolates (NP). For the slow kinetics at $\mathrm{pH} 9$ as shown in Table 1 we think that the surface turns negative and exhibit more amorphous $\mathrm{U}(\mathrm{IV})-\mathrm{OH}-\mathrm{like}$ properties; i.e., oxyhydroxy structures on $\mathrm{U}(\mathrm{IV})_{\mathrm{NPs}}$ surfaces. Thus, the rate of r.d.s. could become slower due to the less available surface-bound hydroxides (-U-OH).

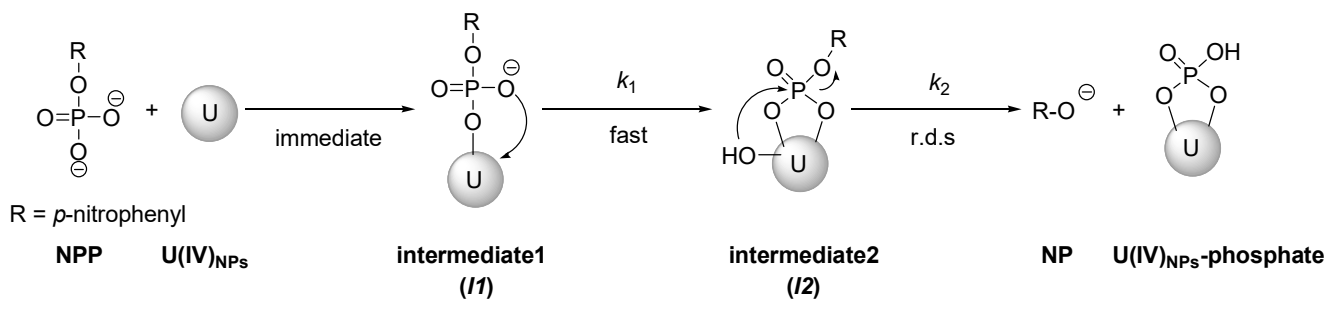

Scheme 1. Proposed mechanism for the hydrolysis of NPP.

\subsubsection{Reaction Modeling Analysis}

Finally, a chemical modeling study was carried out to confirm the reaction mechanism, and the rate constants are listed in Table 1. The kinetic spectrophotometric data were analyzed using the ReactLab ${ }^{\mathrm{TM}}$ KINETICS program (see Figures S9-S11). A series of full spectra, as shown in Figure 2, and the reaction 
model (Equations (2) and (3)), as described below, were subjected to numerical analysis for fitting the global reaction parameters [52,53]. All species, including $\mathrm{U}(\mathrm{IV})_{\mathrm{NPs}}$ that exhibited absorption within the 200-500 $\mathrm{nm}$ wavelength range, were included in the model. However, for the first reaction (Equation (1)), producing I1 was excluded from the model because it was overly fast, and thus could not be monitored in this study. The $\mathrm{p} K_{\mathrm{a}}$ of the NP was also provided to the reaction model as an auxiliary parameter (Equation (4)).

$$
\begin{gathered}
\mathrm{NPP}+\mathrm{U}(\mathrm{IV})_{\mathrm{NPs}} \rightarrow \mathrm{I} 1+\mathrm{U}(\mathrm{IV})_{\mathrm{NPs}}, k_{0} \\
\mathrm{I} 1+\mathrm{U}(\mathrm{IV})_{\mathrm{NPs}} \rightarrow \mathrm{I}+\mathrm{U}(\mathrm{IV})_{\mathrm{NPs}}, k_{1} \\
I 2+\mathrm{U}(\mathrm{IV})_{\mathrm{NPs}} \rightarrow \mathrm{NP}+\mathrm{U}(\mathrm{IV})_{\mathrm{NPs}}, k_{2} \\
\mathrm{NPH} \leftrightarrow \mathrm{NP}^{-}+\mathrm{H}^{+}, p K_{a}=7.15 .
\end{gathered}
$$

Overall, such a reaction model analysis was successful for $\mathrm{pH}$ values between 6 and 9 , where the emergence of the spectral band $(\sim 400 \mathrm{~nm})$ of the NP (the reaction product) was evident. At $\mathrm{pH} 7$, the pseudo-first order rate constants we calculated were $5.7 \times 10^{-2} \mathrm{~s}^{-1}$ for $k_{1}$ and $1.4 \times 10^{-3} \mathrm{~s}^{-1}$ for $k_{2}$; note that $k_{2}$ is close to $k_{\mathrm{obs}}\left(2.0 \times 10^{-3} \mathrm{~s}^{-1}\right)$ at $\mathrm{pH} 7$ in Table 1 . The rate constants of the $k_{1}$ level were found to be 10 to 100 times higher than those of the $k_{2}$ level and were $\mathrm{pH}$-dependent (see Figures S9-S11). The $\mathrm{pH}$ dependency of $k_{1}$ likely indicates the acidic property of Intermediate 1 (I1) as that of NPP itself. Thus, we expect that the higher the $\mathrm{pH}$, the more the base (or deprotonated) form of I1, which may be more prone to facilitate the transformation of $I 1$ to $I 2$ (i.e., to induce the higher $k_{1}$ ). All the results calculated from the reaction modeling are demonstrated as a function of $\mathrm{pH}$ in Figure 5 . Generally, the $k_{2}$ values for the rate-determining step match the $k_{\text {obs }}$ values in Table 1 within the same order of magnitude. In addition, an excellent fit between the simulated and experimental spectra was obtained at various pH levels (Figures S9-S11). Thus, we confirm that the model used in this study is appropriate for representing the mediated hydrolysis reaction of $\mathrm{U}(\mathrm{IV})_{\mathrm{NPs}}$.

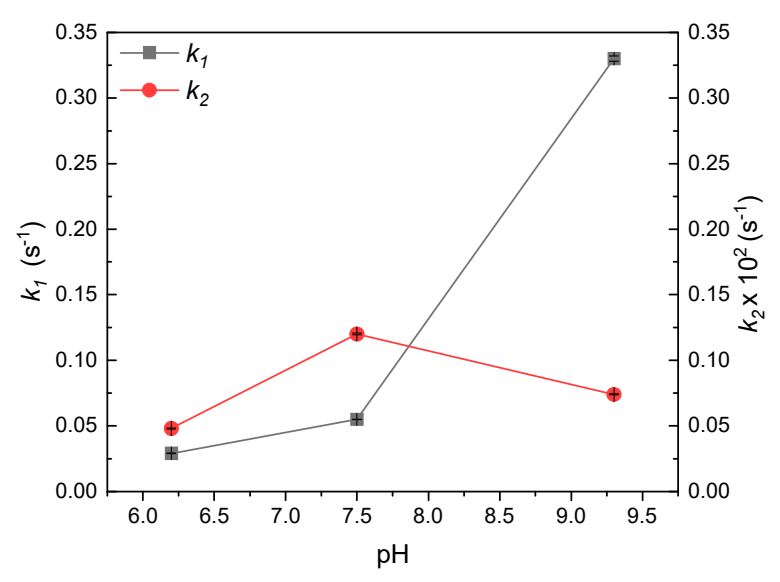

Figure 5. Influence of $\mathrm{pH}$ on the pseudo-first order rate constants, $k_{1}$ (black squares) and $k_{2}$ (red circles), calculated by ReactLab KINETICS program for the NPP hydrolysis mediated by U(IV) $)_{\mathrm{NPs}}$ at $50{ }^{\circ} \mathrm{C}$ for $100 \mathrm{~s}$.

\subsection{Implication of $U(I V)_{N P s}$ Reactivity}

Understanding the speciation, mechanism, and kinetics of $U$ transformation under various conditions relevant to natural and engineered systems is essential to predicting and controlling the migration of $U$ in contaminated environments. Recently, bioreduction accompanied by the phosphate-precipitated $\mathrm{U}(\mathrm{VI})$ phase has been considered as a potential pathway for $\mathrm{U}$ transformation to U(IV)-phosphate mineral phases that could further limit U mobility $[12,14]$. Previous studies have shown that such processes can compete with or limit uraninite formation during the bioreduction of aqueous $\mathrm{U}(\mathrm{VI})$ in the presence of dissolved phosphates [54]. In this study, we demonstrated 
that nanocrystalline $\mathrm{U}(\mathrm{IV})_{\mathrm{NPs}}$ possess their own chemical reactivity toward both inorganic and organic phosphates. Positive surface charges of $\mathrm{U}(\mathrm{IV})_{\mathrm{NPs}}$ formed at acidic to circumneutral $\mathrm{pH}$ levels can strongly drive the surface complexation with anionic ligands, as attested by the measured zeta-potential values of $\mathrm{U}(\mathrm{IV})_{\mathrm{NP}}$-colloids in aqueous solutions and the rapid initial reaction kinetics shown in Scheme 1. Multivalent anions, e.g., phosphates, are very likely to form stable surface complexes on $\mathrm{U}(\mathrm{IV})_{\mathrm{NPs}}$, simultaneously inducing the reduction of their colloidal stability and $\mathrm{U}(\mathrm{IV})$ precipitation. However, the concentration of free orthophosphate is often low in groundwater, and most of the available phosphorus is in the form of organic compounds [55]. Our mechanistic study suggests that organophosphates of microbial metabolic origin, or as supplements of amended treatment in contaminated sites, can rapidly produce phosphate-U(IV) $)_{\mathrm{NPs}}$ complexes that subsequently transform into uranium phosphate precipitates, of which the rate should depend on the U-to-phosphates ratio and $\mathrm{pH}$ in aqueous environments.

\section{Conclusions}

In summary, the synthetic $\mathrm{U}(\mathrm{IV})_{\mathrm{NPs}}$ were shown to be reactive species that can enhance the hydrolysis of NPP, among the other forms of the U(IV) species, at $\mathrm{pH} 3-10$. The positive surface charges and the high surface areas originating from the rough cluster morphology composed of primary particles could be the major factors facilitating the surface adsorption of NPP anions on the U(IV) $)_{\mathrm{NPs}}$ for the hydrolysis. The reaction kinetics and mechanism of the phosphoester cleavage mediated by $\mathrm{U}(\mathrm{IV})_{\mathrm{NPs}}$ were explored in detail. A multi-step reaction mechanism proposed in this study involving two surface complex intermediates, i.e., II and I2, was supported by various spectroscopic data analysis results. Based on our ATR-FTIR studies, we suggest that the inner-sphere surface complexes responsible for inducing the SEIRA of NPP bound to U(IV) $)_{N P s}$ are involved in the rate-determining step of the NPP hydrolysis. Finally, this study indicates that $U(I V)_{N P s}$, owing to the unique nanocolloidal properties, could be one of the major U(IV) species that actively participates in the phosphate-bound $\mathrm{U}(\mathrm{IV})$ mineral formation via interacting with organophosphates in reduced environments. The strategy for $U$ immobilization developed in this study is applicable to transforming colloidal U particles to U-phosphate precipitates and to delaying their potential migration in contaminated sites using organophosphates. Thus, our results will aid understanding chemical behaviors of $U$ species, especially, colloidal $\mathrm{U}$ particles interacting with aqueous phase components in sediments and soils.

Supplementary Materials: The Supplementary Materials are available online: http://www.mdpi.com/2504-5377/ 3/4/63/s1.

Author Contributions: Conceptualization, methodology, software, and validation, H.C. and W.C.; formal analysis, investigation, resources, data curation, and writing-Original draft preparation, H.C.; writing-Review and editing, W.C.; visualization, H.C.; supervision, W.C.; project administration, W.C.; funding acquisition, W.C.

Funding: This research was funded by the Nuclear Research and Development program of the National Research Foundation of Korea, grant number 2017M2A8A5014719.

Conflicts of Interest: The authors declare no conflict of interest. The funders had no role in the design of the study; in the collection, analyses, or interpretation of data; in the writing of the manuscript, or in the decision to publish the results.

\section{References}

1. Kim, J.-I. Significance of actinide chemistry for the long-term safety of waste disposal. Nucl. Eng. Technol. 2006, 38, 459-482.

2. Opel, K.; Weiss, S.; Hübener, S.; Zänker, H.; Bernhard, G. Study of the solubility of amorphous and crystalline uranium dioxide by combined spectroscopic methods. Radiochim. Acta 2007, 95, 143-149. [CrossRef]

3. Kim, J.I. Actinide colloid generation in groundwater. Radiochim. Acta 1991, 52, 71-82. [CrossRef]

4. Maher, K.; Bargar, J.R.; Brown, G.E., Jr. Environmental speciation of actinides. Inorg. Chem. 2012, 52, 3510-3532. [CrossRef] [PubMed] 
5. Geckeis, H.; Rabung, T.; Schäfer, T. Actinide-nanoparticle interaction: Generation, stability and mobility. In Actinide Nanoparticle Research; Springer: Berlin/Heidelberg, Germany, 2011; pp. 1-30. [CrossRef]

6. Fuller, C.; Bargar, J.; Davis, J.; Piana, M. Mechanisms of uranium interactions with hydroxyapatite: Implications for groundwater remediation. Environ. Sci. Technol. 2002, 36, 158-165. [CrossRef] [PubMed]

7. Murray, F.; Brown, J.; Fyfe, W.; Kronberg, B. Immobilization of U-Th-Ra in mine wastes by phosphate mineralization. Can. Mineral. 1983, 21, 607-610.

8. Arey, J.S.; Seaman, J.C.; Bertsch, P.M. Immobilization of uranium in contaminated sediments by hydroxyapatite addition. Environ. Sci. Technol. 1998, 33, 337-342. [CrossRef]

9. Jerden, J.L., Jr.; Sinha, A. Phosphate based immobilization of uranium in an oxidizing bedrock aquifer. Appl. Geochem. 2003, 18, 823-843. [CrossRef]

10. Langmuir, D. Aqueous Environmental Geochemistry; Prentice Hall: Upper Saddle River, NJ, USA, 1997.

11. Martinez, R.J.; Wu, C.H.; Beazley, M.J.; Andersen, G.L.; Conrad, M.E.; Hazen, T.C.; Taillefert, M.; Sobecky, P.A. Microbial community responses to organophosphate substrate additions in contaminated subsurface sediments. PLoS ONE 2014, 9, e100383. [CrossRef]

12. Newsome, L.; Morris, K.; Trivedi, D.; Bewsher, A.; Lloyd, J.R. Biostimulation by glycerol phosphate to precipitate recalcitrant uranium (IV) phosphate. Environ. Sci. Technol. 2015, 49, 11070-11078. [CrossRef]

13. Newsome, L.; Morris, K.; Lloyd, J.R. The biogeochemistry and bioremediation of uranium and other priority radionuclides. Chem. Geol. 2014, 363, 164-184. [CrossRef]

14. Stetten, L.; Blanchart, P.; Mangeret, A.; Lefebvre, P.; Le Pape, P.; Brest, J.; Merrot, P.; Julien, A.; Proux, O.; Webb, S.M. Redox fluctuations and organic complexation govern uranium redistribution from $\mathrm{U}$ (IV)-phosphate minerals in a mining-polluted wetland soil, Brittany, France. Environ. Sci. Technol. 2018, 52, 13099-13109. [CrossRef] [PubMed]

15. Morin, G.; Mangeret, A.; Othmane, G.; Stetten, L.; Seder-Colomina, M.; Brest, J.; Ona-Nguema, G.; Bassot, S.; Courbet, C.; Guillevic, J. Mononuclear U (IV) complexes and ningyoite as major uranium species in lake sediments. Geochem. Perspect. Lett. 2016, 2, 95-105. [CrossRef]

16. Ingall, E.D.; Schroeder, P.A.; Berner, R.A. The nature of organic phosphorus in marine sediments: New insights from ${ }^{31}$ P NMR. Geochim. Cosmochim. Acta 1990, 54, 2617-2620. [CrossRef]

17. Espinosa, M.; Turner, B.L.; Haygarth, P.M. Preconcentration and separation of trace phosphorus compounds in soil leachate. J. Environ. Qual. 1999, 28, 1497-1504. [CrossRef]

18. Pant, H.; Warman, P.; Nowak, J. Identification of soil organic phosphorus by ${ }^{31} \mathrm{P}$ nuclear magnetic resonance spectroscopy. Commun. Soil Sci. Plant Anal. 1999, 30, 757-772. [CrossRef]

19. Benitez-Nelson, C.R. The biogeochemical cycling of phosphorus in marine systems. Earth-Science Reviews 2000, 51, 109-135. [CrossRef]

20. Turner, B.L.; McKelvie, I.D.; Haygarth, P.M. Characterisation of water-extractable soil organic phosphorus by phosphatase hydrolysis. Soil Biol. Biochem. 2002, 34, 27-35. [CrossRef]

21. Paytan, A.; McLaughlin, K. The oceanic phosphorus cycle. Chem. Rev. 2007, 107, 563-576. [CrossRef]

22. Balistrieri, L.S.; Chao, T. Adsorption of selenium by amorphous iron oxyhydroxide and manganese dioxide. Geochim. Cosmochim. Acta 1990, 54, 739-751. [CrossRef]

23. Baldwin, D.S.; Beattie, J.K.; Coleman, L.M.; Jones, D.R. Phosphate ester hydrolysis facilitated by mineral phases. Environ. Sci. Technol. 1995, 29, 1706-1709. [CrossRef] [PubMed]

24. Baldwin, D.S.; Beattie, J.K.; Coleman, L.M.; Jones, D.R. Hydrolysis of an organophosphate ester by manganese dioxide. Environ. Sci. Technol. 2001, 35, 713-716. [CrossRef] [PubMed]

25. Olsson, R.; Giesler, R.; Loring, J.S.; Persson, P. Adsorption, desorption, and surface-promoted hydrolysis of glucose-1-phosphate in aqueous goethite $(\alpha-\mathrm{FeOOH})$ suspensions. Langmuir 2010, 26, 18760-18770. [CrossRef] [PubMed]

26. Morales-Rojas, H.; Moss, R.A. Phosphorolytic reactivity of o-iodosylcarboxylates and related nucleophiles. Chem. Rev. 2002, 102, 2497-2522. [CrossRef] [PubMed]

27. Sigel, H. Metal Ions in Biological Systems. In The Lanthanides and Their Interrelations with Biosystems; Sigel, H., Sigel, A., Eds.; CRC Press: Basel, Switzerland, 2003; Volume 40, pp. 369-440.

28. Liu, C.; Wang, M.; Zhang, T.; Sun, H. DNA hydrolysis promoted by di-and multi-nuclear metal complexes. Coord. Chem. Rev. 2004, 248, 147-168. [CrossRef]

29. Morrow, J.R.; Iranzo, O. Synthetic metallonucleases for RNA cleavage. Curr. Opin. Chem. Biol. 2004, 8, 192-200. [CrossRef] 
30. Williams, N.H. Models for biological phosphoryl transfer. Biochim. Biophys. Acta 2004, 1697, $279-287$. [CrossRef]

31. Yatsimirsky, A.K. Metal ion catalysis in acyl and phosphoryl transfer: Transition states as ligands. Coord. Chem. Rev. 2005, 249, 1997-2011. [CrossRef]

32. Ott, R.; Krämer, R. Rapid Phosphodiester Hydrolysis by Zirconium(IV). Angew. Chem. Int. Ed. 1998, 37, 1957-1960. [CrossRef]

33. Blaskó, A.; Bruice, T.C. Recent Studies of Nucleophilic, General-Acid, and Metal Ion Catalysis of Phosphate Diester Hydrolysis. Acc. Chem. Res. 1999, 32, 475-484. [CrossRef]

34. Lim, S.; Franklin, S.J. Lanthanide-binding peptides and the enzymes that Might Have Been. Cell. Mol. Life Sci. 2004, 61, 2184-2188. [CrossRef] [PubMed]

35. Luong, T.K.N.; Shestakova, P.; Parac-Vogt, T.N. Kinetic studies of phosphoester hydrolysis promoted by a dimeric tetrazirconium(IV) Wells-Dawson polyoxometalate. Dalton Trans. 2016, 45, 12174-12180. [CrossRef] [PubMed]

36. Cohen, D.; Carnall, W.T. Absorption spectra of Uranium(III) and Uranium(IV) in $\mathrm{DClO}_{4}$ solution 1. J. Phys. Chem. 1960, 64, 1933-1936. [CrossRef]

37. Jolivet, J.P.; Tronc, E.; Chanéac, C. Iron oxides: From molecular clusters to solid. A nice example of chemical versatility. Geomaterials (Mineralogy) 2006, 338, 488-497. [CrossRef]

38. Takasaki, B.K.; Chin, J. Synergistic effect between lanthanum (III) and hydrogen peroxide in phosphate diester cleavage. J. Am. Chem. Soc. 1993, 115, 9337-9338. [CrossRef]

39. Moss, R.A.; Bracken, K.; Zhang, J. Actinide (uranyl) hydrolysis of phosphodiesters. Chem. Commun. 1997, 563-564. [CrossRef]

40. Moss, R.A.; Zhang, J.; Bracken, K. Extraordinary acceleration of phosphodiester hydrolyses by thorium cations. Chem. Commun. 1997, 1639-1640. [CrossRef]

41. Schneider, H.J.; Rammo, J.; Hettich, R. Catalysis of the hydrolysis of phosphoric acid diesters by lanthanide ions and the influence of ligands. Angew. Chem. Int. Ed. 1993, 32, 1716-1719. [CrossRef]

42. Bracken, K.; Moss, R.A.; Ragunathan, K.G. Remarkably rapid cleavage of a model phosphodiester by complexed ceric ions in aqueous micellar solutions. J. Am. Chem. Soc. 1997, 119, 9323-9324. [CrossRef]

43. Breslow, R.; Huang, D.-L. Effects of metal ions, including $\mathrm{Mg}^{2+}$ and lanthanides, on the cleavage of ribonucleotides and RNA model compounds. Proc. Natl. Acad. Sci. USA 1991, 88, 4080-4083. [CrossRef]

44. Griffiths, P.R. Surface-enhanced infrared absorption spectroscopy: Principles and applications. Spectrosc. Prop. Inorg. Organomet. Compd. 2013, 44, 95-122. [CrossRef]

45. Osawa, M.; Ataka, K.-I.; Yoshii, K.; Nishikawa, Y. Surface-enhanced infrared spectroscopy: The origin of the absorption enhancement and band selection rule in the infrared spectra of molecules adsorbed on fine metal particles. Appl. Spectrosc. 1993, 47, 1497-1502. [CrossRef]

46. Osawa, M.; Ikeda, M. Surface-enhanced infrared absorption of p-nitrobenzoic acid deposited on silver island films: Contributions of electromagnetic and chemical mechanisms. J. Phys. Chem. 1991, 95, 9914-9919. [CrossRef]

47. Ahmad, I.; Dines, T.J.; Rochester, C.H.; Anderson, J.A. IR study of nitrotoluene adsorption on oxide surfaces. J. Chem. Soc., Faraday Trans. 1996, 92, 3225-3231. [CrossRef]

48. Osawa, M. Surface-enhanced infrared absorption spectroscopy. In Handbook of Vibrational Spectroscopy; Chalmers, J., Griffiths, P., Eds.; John Wiley \& Sons, Ltd.: Hoboken, NJ, USA, 2006; pp. 785-799. [CrossRef]

49. Li, B.; Raff, J.; Barkleit, A.; Bernhard, G.; Foerstendorf, H. Complexation of U (VI) with highly phosphorylated protein, phosvitin: A vibrational spectroscopic approach. J. Inorg. Biochem. 2010, 104, 718-725. [CrossRef]

50. Klein, A.R.; Bone, S.E.; Bakker, E.; Chang, Z.; Aristilde, L. Abiotic phosphorus recycling from adsorbed ribonucleotides on a ferrihydrite-type mineral: Probing solution and surface species. J. Colloid Interface Sci. 2019, 547, 171-182. [CrossRef]

51. Arai, Y.; Sparks, D.L. ATR-FTIR spectroscopic investigation on phosphate adsorption mechanisms at the ferrihydrite-water interface. J. Colloid Interface Sci. 2001, 241, 317-326. [CrossRef]

52. Maeder, M.; Neuhold, Y.-M. Practical data analysis in chemistry. In Data Handling in Science and Technology; Rutan, S., Walczak, B., Eds.; Elsevier: Oxford, UK, 2007.

53. Maeder, M.; King, P. ReactLab KINETICS; Jplus Consulting Pty Ltd.: East Freemantle, WA, Australia, 2009. 
54. Salome, K.R.; Green, S.J.; Beazley, M.J.; Webb, S.M.; Kostka, J.E.; Taillefert, M. The role of anaerobic respiration in the immobilization of uranium through biomineralization of phosphate minerals. Geochim. Cosmochim. Acta 2013, 106, 344-363. [CrossRef]

55. Turner, B.L.; Papházy, M.J.; Haygarth, P.M.; McKelvie, I.D. Inositol phosphates in the environment. Philos. Trans. R. Soc. Lond. Ser. B Biol. Sci. 2002, 357, 449-469. [CrossRef]

(C) 2019 by the authors. Licensee MDPI, Basel, Switzerland. This article is an open access article distributed under the terms and conditions of the Creative Commons Attribution (CC BY) license (http://creativecommons.org/licenses/by/4.0/). 